\title{
Дворянство и духовенство в системе вертикальной социальной мобильности конца XVII - второй половины XIX века: к вопросу о причинах, побудивших «благородных» перейти в священнослужители
}

\author{
Губаева C.P. \\ Белгородский государственный национальный исследовательский университет, \\ Россия, 308015, г. Белгород, ул. Победы, 85 \\ Email: lady.gubaeva2012@yandex.ru
}

\begin{abstract}
Аннотация. В заявленной статье рассматривается вопрос вертикальной нисходящей социальной мобильности дворян, а именно их переход в священнослужители, который отразил проблемы социального партнерства. Анализ таких исторических источников, как воспоминания, материалы церковной периодики и законодательство Российской империи позволили выявить причины, которые побудили «благородных» покинуть сословие; доказать целенаправленность дворян в изменении социального статуса; раскрыть содержание социально-психологического антагонизма и социального партнёрства между двумя привилегированными социальными группами; обозначить проявление тенденции превращения сельских священников в «барскую прислугу». Изучение новых поведенческих стереотипов дворян в русле смены социального облика целесообразно для формирования представления о проблемах партнёрства поместного дворянства и сельских священников.
\end{abstract}

Ключевые слова: помещик, сельский священник, социальная психология, сословная исключительность, традиции, новации.

Для цитирования: Губаева С.Р. 2021. Дворянство и духовенство в системе вертикальной социальной мобильности конца XVII - второй половины XIX века: к вопросу о причинах, побудивших «благородных» перейти в священнослужители. Via in tempore. История. Политология, 48 (2): 383-393. DOI: 10.52575/2687-0967-2021-48-2-383-393.

\section{The nobility and clergy in the system of vertical social mobility of the late XVII - second half of the XIX century: to the question of the reasons that prompted the «noble» to go to the clergy}

\author{
Svetlana R. Gubaeva \\ Belgorod National Research University, \\ 85 Pobedy St., Belgorod, 308015, Russia \\ Email: lady.gubaeva2012@yandex.ru
}

\begin{abstract}
Annotation. The article considers the issue of vertical downward social mobility of the nobles, namely their transition to the clergy, which reflected the problems of social partnership. The analysis of such historical sources as memoirs, materials of church periodicals and legislation of the Russian Empire allowed: to reveal the reasons that prompted the «noble» to leave the estate; to prove the purposefulness of the nobles in changing their social status; to reveal the content of sociopsychological antagonism and social partnership between two privileged social groups; to indicate the manifestation of the trend of turning rural priests into «lordly servants». The study of new behavioral stereotypes of the nobles in line with the change of social appearance is advisable to form an idea of the problems of partnership between the local nobility and rural priests.
\end{abstract}

Keywords: landowner, village priest, social psychology, class exclusivity, traditions, innovations. 
For citation: Gubaeva S.R. 2021. The nobility and clergy in the system of vertical social mobility of the late XVII - second half of the XIX century: to the question of the reasons that prompted the «noble» to go to the clergy. Via in tempore. History and political science, 48 (2): 383-393 (in Russian). DOI: $10.52575 / 2687-0967-2021-48-2-383-393$.

\section{Введение}

Изучение социально-психологического антагонизма и сотрудничества между представителями российских сословий все больше привлекает внимание современных исследователей, особенно в русле такого направления исторической науки, как социальная история, где можно отметить научные труды Б.Н. Миронова, В.А. Шаповалова, И.В. Истоминой, И.Г. Оноприенко, Д.С. Гудова, А.В. Кузьмина, М.Д. Карпачева и других. Особую актуальность это приобретает при исследовании переломных эпох, где существование социальных противоречий породило внутри- и межсословные перемещения.

Социальная структура российского общества в императорский период неоднократно изменялась, в этом немаловажную роль играла вертикальная социальная мобильность. Изменение количественного показателя ряда сословий находилось в зависимости как от естественного прироста населения в данном сословии, так и от межсословных социальных перемещений [Миронов, 2003, с.133]. Представители отдельных социальных групп стремились «покинуть свое сословие», заметно трансформируя традиционализм, в котором «через определенный психологический механизм представители отдельной социальной группы наследуют прошлые нормы, ценности и правила, которые сохраняются, интерпретируются, используются и передаются различными государственными институтами» [Шаповалов, 2014, с. 429]. Особое место в русле данной парадигмы имеет положение «благородного» дворянства, занимавшего доминирующую роль в сословной структуре Российской империи. Как отмечает В.А. Шаповалов, «дворянство, законодательно поставленное в исключительно привилегированное положение, во многом определяло направленность межсословных отношений в обществе и в целом эволюции российской государственности» [Шаповалов, 2014, с. 4]. Это позволяет исторической науке по-новому подойти к вопросу изучения межсословной мобильности «благородных», в частности исследовать проблему становления дворян священнослужителями, которая до сих пор остается неразрешенной.

Исследование вертикальной нисходящей социальной мобильности дворянства в число священников в конце XVII - второй половины XIX века ставит вопрос о причинах, которые побудили «благородных» покинуть свое сословие. В свою очередь, изучение социального опыта дворян предусматривает такую источниковую базу исследования, как эго-документы. Во-первых, в них ярко выражены маркеры изменения традиционных правил дворянства, во-вторых, их содержание позволяет исследовать социальный опыт людей. Ценным историческим источником являются материалы, опубликованные в таких журналах, как «Черниговские епархиальные известия», «Московские церковные ведомости», «Христианское чтение», в которых на основе исторических справок раскрыта принадлежность священнослужителей к дворянским фамилиям. Необходимо также сделать акцент на эволюцию законодательства в рамках изменений правил приёма в духовенство, которые были сопряжены с утратой прежнего статуса. Данное обстоятельство активизировало социальные лифты, стимулируя вертикальную социальную мобильность.

\section{Объекты и методы исследования}

Объектом в заявленном исследовании являются дворяне как участники социальных перемещений в структуре российского общества в число священнослужителей. Методологическая база исследования обусловлена особенностями научно-исследовательской проблематики. В обозначенной работе была применена теория социальной идентичности при 
анализе самооценки дворян в условиях становления ими священнослужителями. Посредством историко-генетического метода были выявлены причины, а также субъективные и объективные факторы, которые привели к трансформации социального статуса «благородных». Историко-сравнительный метод помог выявить общее и особенное в рамках перехода дворян в священники.

\section{Результаты и их обсуждение}

Первоначально получение священства было доступно каждому желающему служить церкви, но из всех кандидатов на священство самыми подходящими были именно дети духовенства. На это обстоятельство выявлен ряд причин. Во-первых, они по большей части были обучены грамоте. Во-вторых, с детства принимали участие в богослужении вместе со своими отцами. По мере развития государственной жизни российская власть с большей силой выставляла свое требование, чтобы из служилых и тяглых людей никто от службы и тягла «из былых» не был. Такое требование должно было стеснить свободный доступ в духовенство, потому что принимавшие на себя это звание освобождались вместе с потомством от службы и податей [Рождественский, 1887, с. 322]. Таким образом, складывалась практика наследования должностей служителей церкви.

Как справедливо отмечал П. Сорокин: «Никогда не существовало общества, в котором вертикальная социальная мобильность была бы абсолютно свободной, а переход из одного социального слоя в другой осуществлялся бы безо всякого сопротивления [Сорокин, 1992, с. 379]. В этой связи Б.Н. Миронов подчеркивал: «Приходские общины при выборах кандидатов отдавали предпочтение представителям духовенства. Причина простая: прихожане не желали выбирать духовных лиц из своей среды, поскольку за человека, переходящего в состав духовенства из крестьян и посадских, налоги должна была платить его податная община» [Миронов, с. 100], однако «дворяне считали ниже своего достоинства поступать на церковную службу в качестве приходского священника, тем более на должность церковнослужителя» [Миронов, с. 100].

Вместе с тем во второй половине XVII века известны случаи, когда некоторые дворяне изменили своё социальное положение. Они стали основывать в своих имениях церкви и сами же определялись к ним священниками, а потом делались родоначальниками целых, иногда очень длинных дворянско-священнических родов. Например, род Трощановичей Мглинского уезда. Так, Самоквасов - автор заметки «Три документа, относящиеся к истории церкви села Глазова» - указывал, что из описи 1767 года было видно, что Василий Трощанович на собственные средства устроил в селе Дымове храм и к нему был рукоположен в сан священника в 1655 году, а в 1677 году Лазарь Баранович выдал ему священническую грамоту, по словам Филарета, замечательную во многих отношениях [Самсоквасов, 1870, с. 25]. Поскольку дворяне, являясь верхушкой общества, обладали самыми высокими материальными возможностями, то они брали на себя ответственность по строительству церквей.

В русле данной парадигмы интересна личность Феодосия Углицкого. По своему происхождению Феодосий принадлежал к заднепровской дворянской фамилии Углицких, о чем свидетельствует его фамильный дворянский акт. Представляется важным наблюдение исследователя XIX века Г. Барадулина в его труде под названием «Жизнь и деятельность Святого Феодосия Углицкого, архиепископа Черниговского» о его жизненном выборе. Так, в XVII веке в Малороссии белое духовенство много терпело лишений, так как находилось в большой зависимости прежде всего от богатых в влиятельных землевладельцев. Несмотря на это, в Малороссии в обозначенное время многие из лиц дворянского сословия шли в священнослужители. Однако этот порядок со времен учреждения унии был нарушен. Если и случалось, что дворянин, который имел привилегии, выбирал священнослужительскую деятельность, то только призвание к подвигам благочестия и осознание святости избранного дела побуждали вступать в духовное звание [Барадулин, 1897, 
c. 527-528]. Следовательно, принятие священнического сана Углицким было исполнено глубоким благочестием и жаждой вступить в борьбу за охранение православной веры.

Таким образом, имея высокие религиозные искания, «благородные» стремились стать частью духовного мира, при этом одним из основополагающих условий для них было принятие сана священника. Как отмечают социальные психологи, объективная реальность существует независимо от нас, но наблюдаем мы за ней через призму собственных убеждений, установок и нравственных ценностей [Шаповалов, 2012, с. 228]. Однако такие примеры стоит считать в большей степени исключением, чем правилом. В XVII веке приходская церковь считалась семейным достоянием священнослужительских родов.

В законодательстве Российской империи XVIII века разрабатывались меры, которые должны были ликвидировать замкнутость духовенства как сословия. К числу людей, обязанных службой, в первой половине XVIII века принадлежали все дворяне. «Указ о единонаследии» 1714 года дозволил переход из дворянства в духовное звание кадетам, младшим сыновьям дворянских фамилий. Любопытно, что Синод, ссылаясь на обозначенный указ, обозначил особое положение духовенства Малороссии. Этот факт позволяет проследить специфику социального перемещения дворян в Малороссии. Так, А.В. Романович-Славатинский рассматривал в том числе пути, которые позволяли дворянам избежать исполнение своих повинностей. Как отмечал автор, легальной возможности у них не было. Только старость, увечья и неисцеленные болезни избавляли дворянина от лежащего на нем тягла. Петр I законом о единонаследии 1714 года предоставил шляхетству свободу в выборе профессии. Интересные мысли по поводу перехода служилого человека в духовенство встречаем далее. Так, согласно точке зрения Александра Васильевича, между дворянством и духовенством в России не могло образоваться той связи, которая существовала в Западной Европе, где лица самых знатных фамилий поступали в духовное звание и достигали архиерейства и высших ступеней священства. Далее автор указывал, что следствием этого между духовенством и дворянством в Западной Европе была родственная «солидарная» связь; обратная ситуация была в российском обществе, духовенство по своему духу всегда было ближе к народу, а дворянство свысока третировало духовенство. В свою очередь, иначе было в Малороссии, где еще со времен польщины установилась более тесная связь между шляхетством и духовенством. Польские короли в епископы большей частью избирали лиц дворянских фамилий. После присоединения Малороссии к России в духовное звание часто вступали не только рядовые казаки, но и старшины, шляхетство. Многие, согласно точке зрения А.В. Романович-Славатинского, поступали в духовное звание в Малороссии, укрываясь от войсковой службы. Недаром Анна Иоанновна одним из своих указов приписывала Синоду: «архиереям - киевскому, черниговскому и переяславскому - из малороссийской старшины и казаков, и их детей, без аттестатов полковничьи и старшины полковой, а знатных без позволения генеральной войсковой канцелярии в дьяконы и попы посвящать не велено» [Романович-Славатинский, 1912, c. 149-150].

Крайне интересна по своему содержанию записка «Замечания, до Малой России принадлежавшие, с предисловием от действительного члена О. Бодянского», автор которой остался неизвестным. О.М. Бодянский предполагал, что автор этой записки являлся жителем Черниговской губернии. Согласно точке зрения автора, после присоединения Малороссии многие военные и чиновники, избегая службы, приняли священнический сан. Из их числа сложилась особая категория малороссийского духовенства, которые не только считали себя дворянами, но и продолжали оставаться таковыми: они получали из Дворянских комиссий грамоты на дворянство и пользовались всеми дворянскими правами, не выполняя при этом никаких дворянских повинностей, а также владели землей [Бодянский, 1848 , с. 33]. Автор этих замечаний указывал на то, что нужно бы испросить запрет, чтобы в Малой России не смели в противность именных указов принимать в духовное звание в подушном окладе состоящих мещан, казаков и дворян, из числа которых первые убегают 
от рекрутского набора, а последние, уклоняясь от дворянских служб, поступают в духовное звание и пользуются при этом дворянскими выгодами [Бодянский, 1848, с. 34].

В Малороссии уже во второй половине XVII века был велик запрос на образование и «лучшие люди того времени находили возможность удовлетворить своей духовной жажде при самых неблагоприятных условиях» [Стаховский, архиепископ Черниговский, 1897$, с. 78$]$. Очагами распространения образования выступали духовные школы Киева и Харькова. В Киевской академии вместе с детьми духовенства обучались дети служилого дворянства. То же самое можно сказать о Харьковском коллегиуме, но главный контингент давали дети духовенства [Лебедев, 1886, с. 20].

Одним из выдающихся преподавателей Харьковской коллегии был префект Михаил Шванский. Будучи потомственным дворянином древнего рода, он долгое время учился в Киевской академии и в 1765 г. был рукоположен в иереи [Любжин, 2008, с. 253]. Становится очевидна причина, по которой представитель «благородных» Михаил Шванецкий обучался в Киевской академии - это отсутствие высших учебных заведений. Вместе с тем разночинцы редко проходили полный коллегиумский курс. Затем выходили на разные поприща государственной и общественной службы [Лебедев, 1886, с. 21].

Еще одним выпускником Киевской коллегии, принадлежавшим к древней дворянской фамилии, был епископ Черниговский Антоний (Стаховский). Причем его отец и брат были священниками. В то время как одни из родственников Антония шли в духовное ведомство, другие занимали гражданские должности: Андрей Стаховский (Стахович) был городницким сотником [Стаховский, архиепископ Черниговский, 1897, с. 77].

Как указывал П.В. Знаменский, с 1708 г. обучение в славяно-греко-латинских школах для детей духовенства стало обязательным. А дети дворян, начиная с 1715 года, должны были получать образование в Морской академии, Артиллерийской и Инженерной школах [Знаменский, 1881, с. 47]. Обучение в славяно-греко-латинских школах дворянских недорослей разрешалось в виде исключения [Знаменский, 1881, с. 55]. Вместе с тем Петр I дозволил, чтобы «и градские лучшие приказные люди и дворяне» отдавали детей в Московскую славяногреко-латинскую академию. При императрице Анне академия пополнилась отпрысками многих знатных фамилий - в 1736 году по определению Сената в академию поступило 158 дворянских детей, среди которых были князья Оболенские, Хилковы, Тюфякины, Хованские, Голицины, Долгорукие, Мещерские [Смирнов, 1855, с. 107].

Таким образом, становление уровней и типов учреждений российской системы образования в XVII - начале XVIII веков стало предпосылкой для формирования канала вертикальной мобильности из дворян в духовенство. В связи с отсутствием достаточного количества учебных заведений коллегиумы и славяно-греко-латинские / славяно-русские школы осуществляли общеобразовательную и профессиональную подготовку как будущих священников, так и гражданских и военных специалистов. На наш взгляд, эта ситуация создавала благоприятные условия для выбора детьми дворян священнослужения как профессии.

Следующим моментом в социальном сближении дворянства и духовенства стала «Жалованная грамоты дворянству» 1785 г., которая позволила дворянству выбирать любую профессиональную стезю, а не только военную. Спустя восемь лет - в 1797 г. - был принят указ о запрещении применения телесных наказаний к дворянам, гильдейским купцам, священникам и диаконам. П.В. Знаменский обозначил, что дарование священникам того права, которое было присуще только «благородным», как и ликвидация его тогда, когда его лишились дворяне, показывало, что духовенство, согласно воззрения правительства, считалось уже привилегированным сословием [Знаменский, 1880, с. 158].

Таким образом, в течение XVIII - первой половины XIX века происходило расширение прав и привилегий духовенства. Помимо освобождения от подушной подати и воинской повинности духовенство освободилось от телесных наказаний. До 60-х годов XIX века духовенство можно было определить как сословие полупривилегированное 
[Иванова, Желтова, 2010, с. 266]. Несмотря на разность в определении положения духовенства как «привилегированное» или «полупривилегированное» сословие, очевидно, что духовенство в Российской империи имело статус «особого сословия».

Однако полного сближения социального статуса дворянства и духовенства не произошло. Кроме этого, сближению мешала традиция выбора детьми дворян военной службы как приоритетной сферы приложения профессиональных усилий.

Так, дворянин Болотов, характеризуя в своих мемуарах современников, которые происходили из духовенства и отличались благородными качествами, каждый раз считал нужным прибавить к своей похвале выразительное «не взирая на его породу» [Знаменский, 1873, с. 104]. Именно в этом восприятии выражался социально-психологический антагонизм, иллюстрирующий в дворянине и в священнике два антимира, сведенные воедино в рамках привилегированного положения. Внешний облик, быт, манеры, образованность подчеркивали недосягаемую сословную статусность дворянства [Шаповалов, 2013, c. 89].

В этой связи становится очевидным, почему «благородные» стали реже вступать в духовное звание и стремились покинуть его, если принадлежали к нему ранее. Так, например, в 1803 г. студент Петербургской духовной академии Андруцкий - сын священника, узнав, что он является дворянином, «нисколько немедля оставил и философию, и школу, чтобы избрать новый род жизни, соответствующий его склонностям, равно и правам, представленным благородному дворянству» [Чистович, 1857, с. 144-145]. П.В. Знаменский связывал это с тем, что студенты не хотели быть священниками, не хотели быть на пашне и во многом зависеть от власти помещиков, на которых выходили жалобы, а управу сыскать было трудно [Знаменский, 1873, с. 117].

Однако были и примеры того, что дворяне сознательно выбирали священническое служение. Так, профессор Санкт-Петербургского университета Я.В. Толмачев (1779-1873) в «Автобиографической записке» указывал, что его прадед бы дворянином, переселившимся с частью своих крестьян из села Толмачевки Курского уезда в село Тишки Харьковского уезда, где он принял священнический сан [Толмачев, 1892, с. 700].

Фрейлина русского императорского двора Александра Осиповна Смирнова-Россет упоминала в своих воспоминаниях следующий факт: «В 40 верстах жила тетушка Екатерина Ивановна Вороновская, ее муж Артемий Ефимович был сын священника из дворян. В Малороссии часто были священники из дворян и были лучшие помещики, а их крестьяне - лучшие работники. Доктор Оболевский был сын священника из дворян, также и почтенный старец Павловский» [Смирнова-Россет, 1990, с. 40].

В своих записках надворный советник Григорьев И.Г. отмечал, что его отец был сыном священника села Тумы Якима Федотова. Кроме того, он отмечал, что его отец принадлежал древней дворянской фамилии Пожарских, но в годы Смуты перешел из воинского звания в духовное [Григорьев, 1899, с. 11].

Епископ Леонид (Краснопевков) происходил из семьи дворян, получил светское образование и трудился чиновником в морском ведомстве. Однако в результат его духовной жизни он принял решение постричься в монахи. Митрополит Московский Филарет (Дроздов) дал ему следующую рекомендацию в письме к наместнику Троице-Сергиевой лавры: «В академию поступает чиновник из дворян, Краснопевков. Это не то, что некоторые бывшие пред ним. Примите его со вниманием и дайте ему право узнать обитель и монашество» [Корсунский, 1893, с. 216]. А во время его хиротонии он указал на следующее обстоятельство: «Благодари, боголюбезный, Всепромыслителя Бога, который указал тебе путь жизни, не указанный твоим рождением, и вел тебя добрым желанием, а иногда и затруднениями, и скорбями, всегда к миру» [Корсунский, 1893, с. 217].

Наиболее показательной, на наш взгляд, является судьба епископа Игнатия (Брянчанинова). В миру - Дмитрий Александрович Брянчанинов, родился в 1807 в старинной дворянской семье. По семейной традиции он поступил в Петербургское инженерное учи- 
лище не по своему избранию и желанию. Следующим образом вспоминал об этом Игнатий (Брянчанинов): «Иду по улицам Петербурга в мундире юнкера, и слезы градом льются из очей... Я сожалел о юнкерском мундире: в нем можно было, приходя в храм Божий, стать в толпе солдат, в толпе простолюдинов, молиться и рыдать, сколько душе угодно... мой ум был весь погружен в науки и вместе горел желанием узнать, где кроется истинная вера, где кроется истинное учение о ней, чуждое заблуждений и догматических, и нравственных» [Рункевич, 1895, с. 555]. Узнав о духовных исканиях сына, его отец обратился с просьбой к начальнику училища о запрещении ему посещений Александро-Невской лавры.

Окончательное решение о принятии монашества им было принято в 1826 году после беседы со старцем Леонидом (Наголкиным) (в схиме - Лев). После окончания выпускных экзаменов Дмитрий подал прошение об отставке. Это решение вызвало неприятие не только у его родителей, но у императора Николая I, который курировал свое любимое детище - инженерное училище и его талантливых выпускников, к числу которых относился и Д. Брянчанинов. Государь поручил своему брату великому князю Михаилу Павловичу переубедить Дмитрия. Но их разговор завершился приказом о назначении Д. Брянчанинова инженером в Динабургскую крепость с указанием о его исполнении «в двадцать четыре часа». В Динабурге Д. Брянчанинов тяжело заболел, и его просьба об отставке была принята в 1827 г. После этого он поехал в Александро-Свирский монастырь, где пребывал под духовным руководительством старца Леонида. В 1831 г. он был пострижен в монашество с именем Игнатий [Рункевич, 1895, с. 556-557].

В ходе Великих реформ была ликвидирована практика наследования священнических и дьяконских мест родственниками. В 1867 г. было отменено преимущественное право на занятие детей или родственников мест священнослужителей [Фирсов, 2002, c. 23]. В 1869 г. и 1871 г. представителям всех сословий было разрешено занимать церковные должности, принципиально, однако, «не изменивший устоявшийся порядок вещей, а скорее способствовавший бегству молодых поповичей из рядов своего сословия» [Карнишина, 2010, с. 26]. Согласно нормам российского законодательства, принятие священнического сана дворянином предполагало выход из своего сословия. Более того, в случае снятия с себя сана бывший дворянин уже не имел возможности вернуться в дворянское сословие, а приравнивался к простолюдину. То же самое происходило и с его детьми [Знаменский, 1873, с. 118].

В этой связи представляется интересной судьба московского священника И.В. Арсеньева, который был сыном потомственного дворянина В.С. Арсеньева и Н.Ю. Арсеньевой (урожденной княжны Долгорукой). По достижении 17-летнего возраста он поступил в Московскую духовную семинарию. Причем его поступление было отмечено в речи ректора семинарии. Н. Благоразумов, который указал на то, что поступление в семинарию дворян явление новое, при этом выразил надежду, что подобного рода действие сможет послужить сближению церкви и интеллигенции. После окончания семинарии И.В. Арсеньев продолжил свое образование в Московской духовной академии. И в 1892 г. начал свое священническое служение в домовом храме Московского учительского института [Гончаров, 2011, с. 117-118].

В художественной литературе XIX века сохранилось упоминание о материальном мотиве принятия дворянами священнического сана в пореформенный период. Так, героя рассказа А.И. Краснопольского «Деревенские дельцы» молодого разорившегося помещика Юрия Селиверстовича Фистулова на обеде в честь именин местного священника - отца Ильи - посетила мысль: «нельзя ли как-нибудь по новому положению попасть в попы? Сколько гостей, и всех здесь упитают, а ты один - и то сидишь голодный в родительском домишке...» [Краснопольский, 1878, с. 170].

На основе вышеприведенного отрывка прослеживается, что пореформенный период сопровождался трудностями изменения привычного уклада жизни дворян, ощущением 
психологического дискомфорта. Как справедливо отмечает В.А. Шаповалов: «Модернизация поместных хозяйств, как и поддержание привычного «барского» быта, требовали больших денег, но их у большинства помещиков в наличии не было» [Шаповалов, 2010, c. 135]. В свою очередь, именно новизна, отрицавшая привычный поместный традиционализм, и была фактором психологического помещичьего дискомфорта [Шаповалов, 2010, c. 133]. Социальный упадок поместного дворянства, пессимизм, тревожное психологическое состояние привели к поиску нового пути улучшения материального положения. Одним из вариантов решения проблемы мог быть переход в попы. Но, как в начале прозвучало, отец Илья был из среды зажиточных священнослужителей.

Однако молодой помещик отказался от этой идеи, когда отец Илья задал ему вопрос, не желал ли он пойти в священники. Следующее ответил Юрий Селиверстович: «Я уж думал, но избави Боже, помилуйте, соборовать старуху умирающую, видеть ее предсмертную агонию, утешать, потом хоронить какую-нибудь красавицу, быть свидетелем раздирающую душу плача. Потом: замерзать в поле, на пути к больному, в ночь и за полночь. Да я лучше в пастухи под скотину наймусь, чем». Примечательно то, что ответил по данному случаю о. Илья: «Нет, вы еще не знаете, что священник есть бессменный часовой по все триста шестьдесят пять дней в году... Ты только раздвинешь руки во время Херувимской и весь отдаешься Богу, хвать пономарь докладывает: Ванька в машину попал, дыхнет и нет. Отпускай руки, отпускай в преисподнюю душу, отпускай из церкви народ, спеши к Ваньке. А не пойдешь, так тебе косу отрежут, или в монастырь сошлют, воду носить монахам на самовар» [Краснопольский, 1878, с. 175].

Указанный литературный пример доказывает, что далеко не всегда выбор в изменении социальной принадлежности имел среди помещиков нравственную сторону, это подтверждает, что только истинная целенаправленность дворян приводила к изменению их социального статуса.

Уже в пореформенное время дворянство стало постепенно утрачивать свои сословные привилегии, сближаясь в правовом положении с другими сословиями [Миронов, 2003, с. 94]. К концу ХІХ века окончательно сломались сословные границы духовного чина. Если архиереи из дворян в XIX веке были редким исключением, то сословное происхождение архиереев первой половины XX века имеет яркие примеры представителей «благородного» сословия: из дворян происходили Патриарх Алексий (Симанский), митрополит Трифон (князь Туркестанов), епископ Андрей (князь Ухтомский) и другие [Цыпин, 2010, с. 324-325].

\section{Заключение}

Таким образом, дворянство, оказавшись в системе вертикальной нисходящей социальной мобильности, целенаправленно подходило к данному выбору. Имея высокие религиозные чувствования, «благородные» стремились стать частью духовного мира. Вместе с тем, на наш взгляд, новоприобретенный социальный облик служил своего рода индикатором принадлежности к привилегированному сословию. В настоящее время не представляется возможным установить количественный состав православных священников - выходцев из дворянского сословия. Однако приведённые примеры позволяют утверждать, что такие случаи были единичны. Это было связано с тем, что переход в духовное сословие предполагал безвозвратное лишение дворянских привилегий. В рассматриваемом контексте необходимо учитывать, что данное обстоятельство было порождено в том числе социальными противоречиями между дворянами и духовенством, а именно презрительным отношением многих помещиков к священникам, приравненным в их сознании к холопам.

\section{Благодарности}

Автор выражает глубокую благодарность научному руководителю, доктору исторических наук, профессору Владимиру Анатольевичу Шаповалову. 


\section{Список литературы}

1. Барадулин Г. 1897. Жизнь и деятельность Святого Феодосия Углицкого, архиепископа Черниговского. Христианские чтения. Т. 4: 517-536.

2. Бодянский О. 1848. Замечания, до Малой России принадлежавшие. С предисловием действительного члена О. Бодянского. Издание императорского общества истории и древностей российских. Т. 1: 1-55.

3. Гончаров В.А. 2011. «Необходимо созвать новый вселенский собор, и в этом ближайшая и неотложная задача церкви». Докладная записка кафедрального протоиерея Иоанна Арсеньева святейшему патриарху Тихону (Беллавину). Вестник Православного СвятоТихоновского гуманитарного университета. История Русской Православной Церкви. 6: 117-144.

4. Григорьев И.Г. 1899. Современные записки надворного советника Ивана Григорьевича Григорьева, им самим написанные. С.-Петербург, 1802 г. Детям моим. Лященко А. Записки И.Г. Григорьева. Санкт-Петербург, Типография Р. Голике: 11-18.

5. Знаменский П.В. 1881. Духовные школы в России до реформы 1808 г. Казань, Типография Императорского университета, 807.

6. Знаменский И.П. 1880. Положение духовенства в царствование Екатерины II и Павла І. Москва, Типография М.Н. Лаврова и К, 186.

7. Знаменский П.В. 1873. Приходское духовенство в России со времени Петра I. Казань, Университетская типография, 851.

8. Иванова Н.А., Желтова В.П. 2010. Сословное общество Российской империи (XVIII начало XX века). Москва, Хронгограф, 752.

9. Карнишина Н.Г. 2010. Церковные реформы в России во второй половине XIX века. Москва, Издательство ПСТГУ, 176.

10. Краснопольский А.И. 1878. Деревенские дельцы. Вестник Европы. Т. 5: 125-177.

11. Лебедев А.С. 1886. Харьковский коллегиум как просветительский центр Слободской Украины до учреждения в Харькове университета. Москва, университетская типография на Страстном бульваре, 103.

12. Любжин А.И. 2008. Харьковский коллегиум в XVIII - начале XIX. Вопросы образования. 3: 240-263.

13. Миронов Б.Н. 2003. Социальная история России периода империи (XVIII - начало XX в.). Санкт-Петербург, Дмитрий Буланин, 548.

14. Рождественский В. 1887. Заметки и сообщения о печати. Московские церковные ведомости. 22: 322.

15. Рункевич С.Г. 1895. Письма аскета: из переписки архим. Игнатия Брянчанинова с С.Д. Нечаевым. Христианское чтение. 5-6: 553-595.

16. Самоквасов. 1870. Три документа, относящиеся к истории церкви села Глазова. Черниговские епархиальные известия. 2: 22-26.

17. Смирнов С.К. 1855. История Московской славяно-греко-латинской академии. Москва, Типография В. Готье, 428.

18. Смирнова-Россет А.О. 1990. Воспоминания. Письма. Москва, Правда, 540.

19. Сорокин П.А. 1992. Человек. Цивилизация. Общество. Москва, Политиздат, 543.

20. Стаховский Антоний, архиепископ Черниговский. 1897. Черниговские епархиальные известия. 2: 75-81.

21. Толмачев Я.В. 1892. Автобиографическая записка. Русская старина. 9: 699-706.

22. Фирсов С.С. 2002. Русская Церковь накануне перемен (конец 1890-х - 1918 гг.). Москва, Культурный центр «Духовная библиотека», 637.

23. Чистович И.А. 1857. История Санкт-Петербургской духовной академии. СанктПетербург, Типография Якова Трея, 462.

24. Цыпин В. 2010. РПЦ в синодальную эпоху. 1700-1917 гг. Москва, Издательство Сретинского монастыря, 816.

25. Шаповалов В.А. 2014. Дворянство Центрально-Черноземного региона России в пореформенный период. Москва, ИД «Белгород» НИУ «БелГУ», 544.

26. Шаповалов В.А. 2013. «На Руси дворянин, кто за многих один»: позитивное отношение к помещику в русском народном фольклоре (на примере пословиц и поговорок). Научные ведомости БелГУ. Серия История. Политология. Экономика. Информатика. 22: 87-91. 
27. Шаповалов В.А. 2010. Отмена крепостного права и русские помещики в очерке «Увертюра» из цикла «Оскуднение» С.Н. Терпигорева (С. Атавы). Научные ведомости БелГУ. Серия История. Политология. Экономика. Информатика. 1: 128-136.

28. Шаповалов В.А. 2012. Провинциальное дворянство и выработка проектов реформы отменены крепостного права: социально-психологический аспект (на примере Центрального Черноземья). Проблемы истории филологии и культуры. 35: 226-235.

\section{References}

1. Baradulin G. 1897. Zhizn' i dejatel'nost' Svjatogo Feodosija Uglitskogo, arhiepiskopa Chernigovskogo [The Life and Work of Saint Theodosius of Uglitz, Archbishop of Chernigov]. Hristianskie chtenija. T. 4: 517-536 (in Russian).

2. Bodjanskij O. 1848. Zamechanija, do Maloj Rossii prinadlezhavshie. S predisloviem dejstvitel'nogo chlena O. Bodjanskogo [Comments that belonged to Little Russia before. With a foreword by the full member O. Bodyansky]. Izdanie imperatorskogo obschestva istorii i drevnostej rossijskih. T. 1: 1-55 (in Russian).

3. Goncharov V.A. 2011. «Neobhodimo sozvat' novyj vselenskij sobor, i v 'etom blizhajshaja i neotlozhnaja zadacha tserkvi». Dokladnaja zapiska kafedral'nogo protoiereja Ioanna Arsen'eva svjatejshemu patriarhu Tihonu (Bellavinu) [«It is necessary to convene a new ecumenical council, and this is the immediate and urgent task of the church». Memo of the Cathedral Archpriest John Arsenyev to His Holiness Patriarch Tikhon (Bellavin)]. Vestnik Pravoslavnogo Svjato-Tihonovskogo gumanitarnogo universiteta. Istorija Russkoj Pravoslavnoj Tserkvi. 6: 117-144 (in Russian).

4. Grigor'ev I.G. 1899. Sovremennye zapiski nadvornogo sovetnika Ivana Grigor'evicha Grigor'eva, im samim napisannye [Modern notes of the court adviser Ivan Grigorievich Grigoriev, written by himself]. St. Petersburg, 1802 g. Detjam moim. Ljaschenko A. Zapiski I.G. Grigor'eva. Spb., Tipografija R. Golike, 11-18 (in Russian).

5. Znamenskij P.V. 1881. Duhovnye shkoly v Rossii do reformy $1808 \mathrm{~g}$ [Ecclesiastical schools in Russia before the reform of 1808]. Kazan', Tiografija Imperatorskogo universiteta, 807 (in Russian).

6. Znamenskij I.P. 1880. Polozhenie duhovenstva v tsarstvovanie Ekateriny II i Pavla I [The position of the clergy in the reigns of Catherine II and Paul I]. Moscow, Tipografija M.N. Lavrova i K, 186 (in Russian).

7. Znamenskij P.V. 1873. Prihodskoe duhovenstvo v Rossii so vremeni Petra I [Parish clergy in Russia since the time of Peter the Great]. Kazan', Universitetskaja tipografija, 851 (in Russian).

8. Ivanova N.A., Zheltova V.P. 2010. Soslovnoe obshchestvo Rossiyskoy imperii (XVIII nachalo XX veka) [Estate Society of the Russian Empire (XVIII - early XX century)]. Moscow, Hrongograf, 752 (in Russian).

9. Karnishina N.G. 2010. Tserkovnye reformy v Rossii vo vtoroj polovine XIX veka [Church reforms in Russia in the second half of the XIX century]. Moscow, Izdatel'stvo PSTGU, 176 (in Russian).

10. Krasnopol'skij A.I. 1878. Derevenskie del'tsy [Village businessmen]. Vestnik Evropy. T. 5, 125-177 (in Russian).

11. Lebedev A.S. 1886. Har'kovskij kollegium kak prosvetitel'skij tsentr kak prosvetitel'skij tsentr Slobodskoj Ukrainy do uchrezhdenija $\mathrm{v}$ Har'kove universiteta [Kharkiv Collegium as an educational center as an educational center of Sloboda Ukraine before the establishment of a university in Kharkiv]. Moscow, universitetskaja tipografija na Strastnom bul'vare, 103 (in Russian).

12. Ljubzhin A.I. 2008. Har'kovskij kollegium v XVIII - nachale XIX [Kharkiv Collegium in the XVIII - early XIX century]. Voprosy obrazovanija. 3: 240-263 (in Russian).

13. Mironov B.N. 2003. Sotsial'naja istorija Rossii perioda imperii (XVIII - nachalo XX v.) [Social History of Russia during the Imperial period (XVIII - early XX century)]. St. Petersburg, Dmitrij Bulanin, 548 (in Russian).

14. Rozhdestvenskij V. 1887. Zametki i soobschenija o pechati [Notes and print messages]. Moskovskie tserkovnye vedomosti. 22: 322 (in Russian).

15. Runkevich S.G. 1895. Pis'ma asketa: iz perepiski arhim. Ignatija Brjanchaninova s S.D. Nechaevym [Letters of the ascetic: from the correspondence of Archimedes. Ignatiya Bryanchaninov with S.D. Nechaev]. Hristianskoe chtenie. 5-6: 553-595 (in Russian).

16. Samokvasov. 1870. Tri dokumenta, otnosjaschiesja k istorii tserkvi sela Glazova [Three documents related to the history of the church of the village of Glazov]. Chernigovskie eparhial'nye izvestija. 2: 22-26 (in Russian). 
17. Smirnov S.K. 1855. Istorija Moskovskoj slavjano-greko-latinskoj akademii [History of the Moscow Slavic-Greek-Latin Academy]. Moscow, Tipografija V. Got'e, 428 (in Russian).

18. Smirnova-Rosset A.O. 1990. Vospominanija. Pis'ma [Memories. Letters]. Moscow, Pravda, 540 (in Russian).

19. Sorokin P.A. 1992. Chelovek. Tsivilizatsija. Obschestvo [Person. Civilization. Society]. Moscow, Politizdat, 543 (in Russian).

20. Stahovskij Antonij, arhiepiskop [Chernigovskij Anthony of Stakhovsky, Archbishop of Chernihiv]. 1897. Chernigovskie eparhial'nye izvestija. 2: 75-81 (in Russian).

21. Tolmachev Ja.V. 1892. Avtobiograficheskaja zapiska [Autobiographical note Russkaja starina]. 9: 699-706 (in Russian).

22. Firsov S.S. 2002. Russkaja Tserkov' nakanune peremen (konets $1890-\mathrm{h}-1918$ gg.) [The Russian Church on the Eve of Change (Late 1890s - 1918)]. Moscow, Kul'turnyj tsentr «Duhovnaja biblioteka», 637 (in Russian).

23. Chistovich I.A. 1857. Istorija Sankt-Peterburgskoj duhovnoj akademii [History of the St. Petersburg Theological Academy]. St. Petersburg, Tipografija Jakova Treja, 462 (in Russian).

24. Tsypin V. 2010. RPTs v sinodal'nuju `epohu. 1700-1917 gg. [The ROC in the Synodal Era]. Moscow, Izdatel'stvo Sretinskogo monastyrja, 816 (in Russian).

25. Shapovalov V.A. 2014. Dvorjanstvo Tsentral'no-Chernozemnogo regiona Rossii v poreformennyj period [The nobility of the Central Black Earth region of Russia in the post-Reform period]. Moscov, ID «Belgorod» NIU «BelGU», 544 (in Russian).

26. Shapovalov V.A. 2013. «Na Rusi dvorjanin, kto za mnogih odin»: pozitivnoe otnoshenie k pomeschiku v russkom narodnom fol'klore (na primere poslovits i pogovorok) [ [In Russia, a nobleman who is one for many»: a positive attitude to the landowner in Russian folk folklore (on the example of proverbs and sayings)]. Nauchnye vedomosti BelGU. Serija Istorija. Politologija. 'Ekonomika. Informatika. 22: 87-91 (in Russian).

27. Shapovalov V.A. 2010. Otmena krepostnogo prava i russkie pomeschiki v ocherke «Uvertjura» iz tsikla «Oskudnenie» S.N. Terpigoreva (S. Atavy) [The abolition of serfdom and Russian landowners in the essay «Overture» from the cycle «Impoverishment» by S.N. Terpigorev (S. Atavy)]. Nauchnye vedomosti BelGU. Serija Istorija. Politologija. `Ekonomika. Informatika. 1: 128-136 (in Russian).

28. Shapovalov V.A. 2012. Provintsial'noe dvorjanstvo i vyrabotka proektov reformy otmeneny krepostnogo prava: sotsial'nopsihologicheskij aspekt (na primere Tsentral'nogo Chernozem'ja) [The provincial nobility and the development of projects for the reform of the abolition of serfdom: a sociopsychological aspect (on the example of the Central Chernozem Region)]. Problemy istorii filologii $\mathrm{i}$ kul'tury. 35: 226-235 (in Russian).

\section{ИНФОРМАЦИЯ ОБ АВТОРЕ}

Губаева Светлана Ренатовна, аспирант кафедры российской истории и документоведения Белгородского государственного национального исследовательского университета, г. Белгород, Россия

\section{INFORMATION ABOUT THE AUTHOR}

Svetlana R. Gubaeva, postgraduate Student, Department of Russian History and Documentation, Belgorod State National Research University, Belgorod, Russia 